\title{
Comparison on Curriculum Setting of Winter Sports in Universities in China, America and Europe
}

\author{
Xiaohua $\mathrm{Wu}$, Zhenzhong Liu \\ Department of Winter Sports, Hebei Sport University, Shijiazhuang, China \\ Email: susan.wuxiaohua@gmail.com
}

How to cite this paper: $\mathrm{Wu}, \mathrm{X}$. H., \& Liu, Z. Z. (2020). Comparison on Curriculum Setting of Winter Sports in Universities in China, America and Europe. Open Journal of Social Sciences, 8, 529-539. https://doi.org/10.4236/jss.2020.83046

Received: March 15, 2020

Accepted: March 28, 2020

Published: March 31, 2020

\begin{abstract}
China has always faced with a huge talent gap in winter sport especially after successful bid for the 2022 winter Olympic Games. As an important base for talents training in winter sports area, many sports colleges and universities in China have set up departments of winter sports to cultivate talents of this field. The text through the method of literature, investigation and interview to collect data, compare the curriculum of related majors of winter sport in China, Europe and United States, learn from the experience of great powers in winter sports to solve the problems existing in the curriculum of major in China. It is believed that the curriculum of winter sports in China is expanded from sports training to leisure sports, while the curriculum of winter sports in Europe and America mainly depends on major of outdoor sports or management. At present, there are great differences between China and foreign countries in terms of curriculum objectives, curriculum content and curriculum system. The reasons for the differences are mainly influenced by history, system and culture. In combination with the actual situation, it is propose that the cultivation of winter sports talents in China should pay attention to the curriculum setting of higher physical education institutions, improve the curriculum setting of winter sports specialty, especially the main theoretical courses, pay attention to the effective connection with practical courses, and explore ways to the sharing teachers and foreign exchanges.
\end{abstract}

\section{Keywords}

Winter Sports, Major, Curriculum Setting, China, America, Europe

\section{Introduction}

On July 31, 2015, Beijing and Zhangjiakou successfully bid for the 24th Winter 
Olympic Games, ushering in a golden period for the development of Chinese winter sports. In China, higher education schools have always been undertaking the training of winter sports talents (Ma \& Lv, 2016). After successful bidding for the 2020 Winter Olympics, multiple sports universities set up winter sports colleges or departments to train talents for winter sports industry (Li, Jiang, \& Sun, 2017; Han, Gu, \& Sun, 2011; Cong, 2007). In the prior research, some researchers explored the issues such as the feasibility of setting up winter sports curriculum, the teaching mode and the faculty development (Wang \& Wang, 2017; Zhang, 2016; Guan, Dong, \& Kang, 2009). However, few relevant researches are conducted on the setting of winter sports curriculum in foreign universities. There is still a lack of well understanding of the specialty curriculums in the leading winter sports European countries and USA. In the face of the emerging establishment of undergraduate winter sports program in universities, how to draw on other countries' experiences and optimize the curriculum to have scientific structure and distinctive characteristics has become a realistic issue that needs to be faced for Chinese winter sports professional talents training.

The author took the opportunity of visiting Europe for academic exchange and visiting the USA for academic study in 2016 to investigate the development of winter sports, the opening of related majors, and curriculum settings in Europe and USA. From the websites of European and the USA universities, the author has an in-depth understanding of winter sports curriculum setting in foreign universities, and makes comparison and analysis to the setting of winter sports curriculum, which provides a theoretical reference for further perfecting Chinese winter sports curriculum setting.

\section{Major Setting: Comparison of Major Setting and Major Name among China, the USA and Europe}

\subsection{The Setting of Winter Sports Majors in Chinese Sports Universities Mainly Relies on Sports Training Majors}

Chinese universities that offer winter sports program are mainly concentrated in the northern China, including professional sports universities and comprehensive universities, and most of them are sports universities (Li, Jiang, \& Sun, 2017). Universities that are the earliest to offer winter sports program include Harbin Sport University, Jilin Sport University and Shenyang Sport University. After China successfully bid for the 2020 Winter Olympics in 2015, Beijing Sport University, Capital University of Physical Education and Hebei Sport University successively added winter sports program enrollment plans, set up winter sports curriculum and train winter sports talents (Table 1). As of April 2018, the winter sports talent training in China has never been affiliated to any major. All universities rely on the second-level major of physical education to set up a major orientation which is not under the management of first-level teaching department, that is, a special department or college. In fact, China's winter sports program initially relied on only sports training. In recent years, they have 
Table 1. Curriculum and major of winter sports in chinese professional sports university.

\begin{tabular}{|c|c|c|c|c|}
\hline School Name & $\begin{array}{c}\text { Initial } \\
\text { Opening Time }\end{array}$ & Course Name & Majors & College \\
\hline $\begin{array}{l}\text { Harbin Sport } \\
\text { University }\end{array}$ & 1956 & $\begin{array}{l}\text { Speed skating, } \\
\text { figure skating, } \\
\text { ice hockey, } \\
\text { curling, alpine skiing, } \\
\text { snowboarding, } \\
\text { snow management }\end{array}$ & $\begin{array}{l}\text { Sports training, } \\
\text { physical education, } \\
\text { Sports Humanities }\end{array}$ & $\begin{array}{c}\text { Winter } \\
\text { Olympic College }\end{array}$ \\
\hline $\begin{array}{l}\text { Jilin Sport } \\
\text { University }\end{array}$ & 1958 & $\begin{array}{c}\text { Speed skating, } \\
\text { figure skating, } \\
\text { ice hockey, Alpine } \\
\text { skiing, snowboarding, } \\
\text { cross-country skiing }\end{array}$ & $\begin{array}{l}\text { Sports training, } \\
\text { leisure sports }\end{array}$ & $\begin{array}{c}\text { Winter } \\
\text { Sports College }\end{array}$ \\
\hline $\begin{array}{l}\text { Shenyang } \\
\text { Sport } \\
\text { University }\end{array}$ & 1954 & $\begin{array}{l}\text { Ice skating, } \\
\text { alpine skiing, } \\
\text { snowboarding }\end{array}$ & $\begin{array}{c}\text { Sports training, } \\
\text { physical education }\end{array}$ & $\begin{array}{c}\text { Winter Sports } \\
\text { Teaching \& } \\
\text { Researching Office }\end{array}$ \\
\hline $\begin{array}{l}\text { Beijing Sport } \\
\text { University }\end{array}$ & 2016 & $\begin{array}{l}\text { Speed skating, } \\
\text { alpine skiing }\end{array}$ & $\begin{array}{c}\text { Sports training, } \\
\text { physical education }\end{array}$ & $\begin{array}{c}\text { Winter } \\
\text { Sports College }\end{array}$ \\
\hline $\begin{array}{l}\text { Hebei Sport } \\
\text { University }\end{array}$ & 2016 & $\begin{array}{l}\text { Speed skating, } \\
\text { alpine skiing, } \\
\text { snowboarding }\end{array}$ & $\begin{array}{l}\text { Sports training, } \\
\text { leisure sports, } \\
\text { social guidance } \\
\text { and management }\end{array}$ & $\begin{array}{c}\text { Winter } \\
\text { Sports } \\
\text { Department }\end{array}$ \\
\hline $\begin{array}{l}\text { Capital } \\
\text { University } \\
\text { of Physical } \\
\text { Education }\end{array}$ & 2017 & $\begin{array}{l}\text { Speed skating, } \\
\text { alpine skiing }\end{array}$ & $\begin{array}{l}\text { Physical education, } \\
\text { sports rehabilitation, } \\
\text { sports economics } \\
\text { and management, } \\
\text { journalism, leisure } \\
\text { sports, social sports } \\
\text { instruction }\end{array}$ & $\begin{array}{l}\text { Winter Sports } \\
\text { Teaching \& } \\
\text { Researching } \\
\text { Office }\end{array}$ \\
\hline
\end{tabular}

Data Source: Official websites of universities and field investigation.

expanded to leisure sports and other majors. In particular, the Capital University of Physical Education has expanded its winter sports enrollment scope to 7 major orientations, trying to train winter sports talents in different majors (Plan, 2017). This brought a new change to original long-term single major support; also it brought new problems to winter sports curriculum setting of different majors.

\subsection{The Setting of Winter Sports Program in the USA Relies on Ski Industry and Snow Resort Management Majors}

In the USA, there are few universities that only offer single sports program, and most sports majors are opened in comprehensive universities (Zhao, Li, \& Li, 2016; Peng, \& Shu, 2014). Some universities offer the winter sports programs of junior-college diploma or undergraduate degree (Catalog, 2017; College, 2018), and their winter sports talent training mode is similar to the winter sports major or orientation in China. For example, Idaho State University and Colorado Mountain College offer winter-sports-related majors, but the major names in different schools are very different. The subordinate majors of winter sports 
program are mostly concentrated in ski industry, outdoor education and snow resort management (Table 2). In the ski industry of University of Maine Farmington, students can choose adaptive ski teaching or professional ski coaching and teaching as the second major while studying other majors (Catalog, 2017). Colorado Mountain College opens 14 ski industry certification programs such as ski industry, ski business, ski rescue and ski patrol. Each program has a corresponding curriculum setting, and some can be used as degree program. In addition, many comprehensive universities in the USA offer ice hockey or ski program according to geographical conditions, but these courses are only used as optional courses in category of general education Catalog, 2017, similar to the winter sports program offered by the comprehensive universities in China.

\subsection{The Setting of European Winter Sports Program Roots on Physical Education and Outdoor Sports}

Europe is the earliest region for developing modern skiing sport in the world (Rudolf, 2013; Carter, 2016). Austria, known as the "Kingdom of Ski", has a special skiing orientation for major of outdoor sports in University of Innsbruck, and its curriculums cover alpine skiing, cross-country skiing and mountaineering skiing (UI, 2018). The German Sport University Cologne offers winter-sports-related optional courses in different majors. The curriculum provision generally covers ice sports, snow sports and winter mountaineering (SUC, 2018) (Table 3). Slovenia, with a population of only 2 million, wins the same medal number as China in the Sochi Winter Olympics and the Department of Physical Education of Ljubljana University also offers winter sports curriculum (UL, 2018). The Telemark College of University College of Trollhattan (Norway) offers winter-sports-related courses in physical education and outdoor sports. These curriculums comprise two modules, each of which is set with 30 credits. One of the modules is based on winter sports, including snowboarding, Alpine

Table 2. Curriculum and major of winter sports in university of USA.

\begin{tabular}{|c|c|c|}
\hline School & Majors & Courses \\
\hline $\begin{array}{c}\text { Colorado } \\
\text { Mountain College }\end{array}$ & $\begin{array}{l}\text { Ski Area Operations, } \\
\text { Ski business }\end{array}$ & $\begin{array}{l}\text { Ski business, ski industry, marketing, } \\
\text { snow making, ski equipment maintenance, } \\
\text { snow resort design, etc. }\end{array}$ \\
\hline $\begin{array}{c}\text { University of } \\
\text { Maine-Farmington }\end{array}$ & Ski Industry & $\begin{array}{l}\text { Alpine skiing, snowboarding, snow resort } \\
\text { management, ski instructor theory, } \\
\text { alpine operations }\end{array}$ \\
\hline $\begin{array}{l}\text { Sierra Nevada College } \\
\quad(\text { Program, 2018) }\end{array}$ & $\begin{array}{c}\text { Ski Business and } \\
\text { Resort Management }\end{array}$ & $\begin{array}{l}\text { Alpine skiing, snowboarding, } \\
\text { ski business introduction, } \\
\text { snow resort operation and sales }\end{array}$ \\
\hline $\begin{array}{l}\text { Idaho State University } \\
\text { (Idaho, 2018) }\end{array}$ & Outdoor Education & $\begin{array}{l}\text { Snowboarding, double-board ski, winter } \\
\text { sports education, avalanche/winter sports } \\
\text { safety, winter survival, ski instructor training }\end{array}$ \\
\hline Lyndon State & Recreation Resource & Alpine skiing, snowboarding, ice hockey, \\
\hline College, Vermont & \& Ski Resort Management & Mountain resort management \\
\hline
\end{tabular}

Source: USA university scholarship website and school websites. 
Table 3. Curriculum and major of winter sport settingin european sports university.

\begin{tabular}{|c|c|c|c|}
\hline Country & School & Majors & Related Courses \\
\hline Germany & $\begin{array}{c}\text { German Sport } \\
\text { University Cologne }\end{array}$ & $\begin{array}{l}\text { Sports management, } \\
\text { sports news, } \\
\text { sports adventure, } \\
\text { sports and health }\end{array}$ & $\begin{array}{l}\text { Alpine skiing, } \\
\text { snowboarding, skating, } \\
\text { biathlon, ski jumping, } \\
\text { winter climbing, } \\
\text { snow hiking }\end{array}$ \\
\hline Norway & $\begin{array}{c}\text { Telemark College, } \\
\text { University College } \\
\text { of Trollhattan }\end{array}$ & $\begin{array}{l}\text { Physical education, } \\
\text { outdoor sports }\end{array}$ & $\begin{array}{c}\text { Alpine skiing, } \\
\text { Nordic skiing, skating, } \\
\text { snowboarding, } \\
\text { Telemark skiing, } \\
\text { ski games }\end{array}$ \\
\hline Austria & $\begin{array}{l}\text { Universitäts-Sportinstitut } \\
\text { der Universität Innsbruck }\end{array}$ & Outdoor sports & $\begin{array}{l}\text { Cross-country skiing, } \\
\text { snowboarding, alpine } \\
\text { skiing, mountaineering } \\
\text { skiing, snow kitten, } \\
\text { snowshoeing }\end{array}$ \\
\hline Slovenia & $\begin{array}{c}\text { Department of Physical } \\
\text { Education, Univerza v Ljubljani }\end{array}$ & $\begin{array}{l}\text { Physical education, } \\
\text { sports training } \\
\text { sports human science }\end{array}$ & $\begin{array}{c}\text { Alpine skiing, } \\
\text { snowboarding, } \\
\text { Nordic skiing, } \\
\text { winter nature activities, } \\
\text { winter activities in } \\
\text { nature, mountain skiing }\end{array}$ \\
\hline
\end{tabular}

skiing, Telemark skiing, Nordic skiing, ice skating, and winter outdoor teaching methods. The other module focuses on teaching methods and outdoor teaching (UCNN, 2018). These module courses can also be used as program of European education bachelor, teaching or international exchange students. On the whole, Europe does not have the major special for winter sports like the USA. Only a few universities have winter sports major program, and their winter sports curriculum are mainly offered by majors of sports education, outdoor sports and sports management.

\section{Comparison of Winter Sports Curriculum Setting among China, the USA and Europe}

In view of the fact that the majors and curriculum setting related to winter sports in Europe and the USA are very different from those in China, and the curriculum names are also very different, it is difficult to conduct an all-round comparison. Based on the possibility of comparison, this research selects partial courses that are similar to each other to carry out analysis in terms of curriculum objective, curriculum content, curriculum implementation, curriculum evaluation and system.

\subsection{Comparison of Curriculum Objectives}

Curriculum objectives are the concentrated expression of teaching training objectives in curriculums ( $\mathrm{Wu}, 2007)$. By taking the cross-country skiing curriculum offered by the universities in Europe, USA and China as an example (Table 4), it shows that the target setting of this curriculum in Europe and USA are 
Table 4. Comparison of curriculum objectives of cross-country skiing in china, USA and Europe.

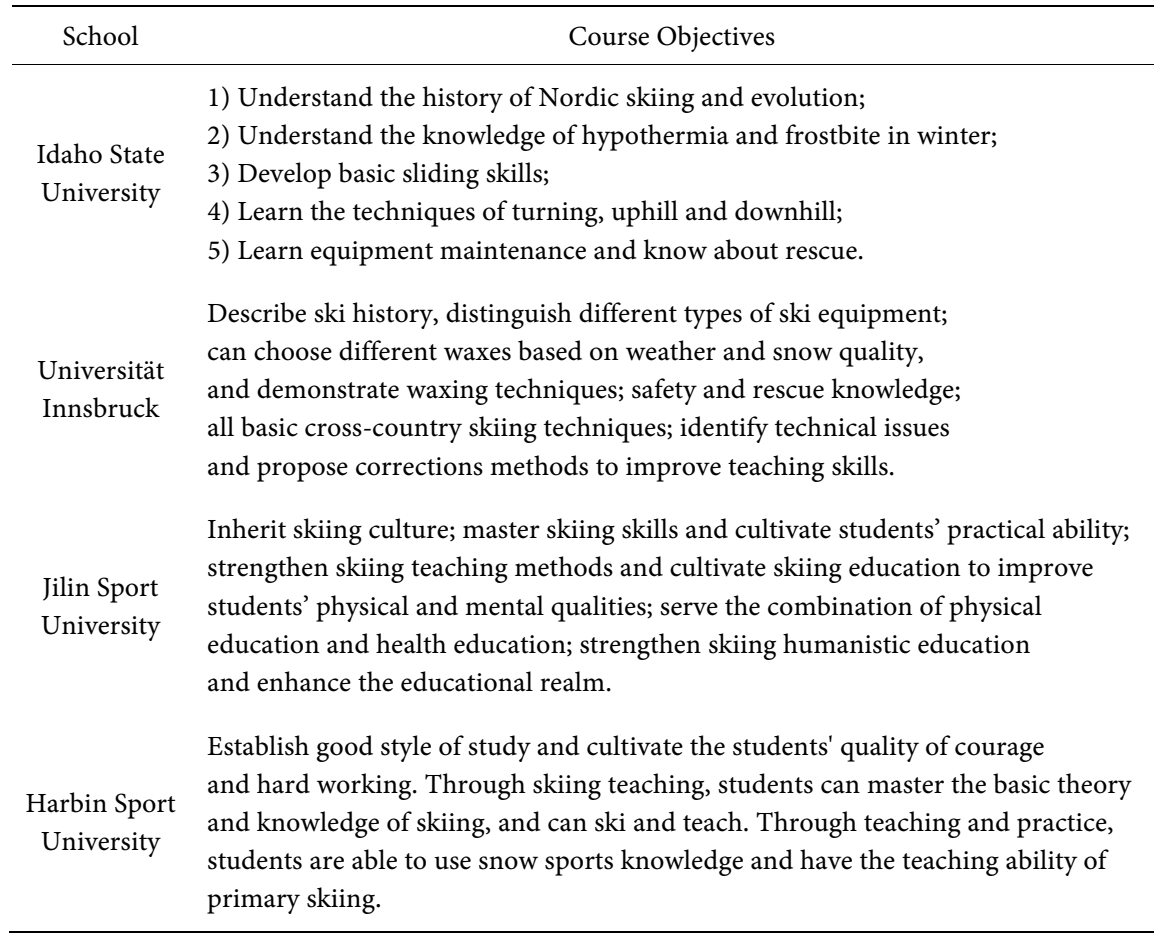

more specific, and each target corresponds to a specific teaching effect, e.g. for study of turning, uphill and downhill techniques, students are required to present 2 kinds of turning methods, 2 kinds of uphill skills and 2 kinds of downhill skills at the end of the course (ISU, 2018). Compared with this, Chinese universities pay more attention to the cultivation of technical ability in term of the curriculum objectives. The objective positioning of course is still mainly based on macro description, and the recognition and understanding of the course is still lack of identification. On the whole, on the one hand, the curriculum objectives in Europe and USA are more hierarchical and progressive, e.g. the course objectives of cross-country skiing require students to have a comprehensive understanding of the program, including weather, history, technology, equipment and rescue. On the other hand, the curriculum objectives in Europe and USA are more comprehensive and directional. The purpose of curriculums is not only to allow students to master basic skills and knowledge, but also to focus on the improvement of comprehensive ability and the cultivation of humanistic quality.

\subsection{Comparison of Curriculum Content}

- From the comparison of the syllabus in different schools, it can be seen that in the selection of teaching content, the coverage of curriculum content in China, Europe and USA tends to be similar, and all include history, technique, venue equipment and safety knowledge, etc. (ISU, 2018; COE, 2018). However, the content of Chinese winter sports curriculum is mainly based on technique, and its theoretical knowledge is preliminary. Some knowledge 
teaching is segmented and separated. That is, after a knowledge point is taught, it is rarely involved in other technical parts, resulting in the students' lacking of systematical work ability. The students' ability in systematical and flexible knowledge application is not high.

- The content of winter sports technique-type curriculum in Europe and USA is more open. For example, for the maintenance of winter sports equipment and the use of venue equipment, students may achieve better learning results through field operations, which can fully reflect the objectives of curriculum have clear levels and pay more attention to practical applications. In addition, in the arrangement of teaching activities reflected in the syllabus at home and abroad, most of the teaching modes in China are mainly class lecture, while Europe and USA introduce seminar, guest lectures, skill presentation and practical operations into the class. In Europe and USA, the arrangement of teaching activities applied to various teaching contents is also flexible, and the organization of curriculum content pays more attention to practicality and timeliness (Peng, \& Shu, 2014; Liu, 2011).

\subsection{Comparison of Curriculum Implementation}

A famous Chinese curriculum theory researcher, said, "Curriculum implementation is a means to achieve the expected educational results" (Zhong, 2008). The implementation of physical education curriculum is not the mechanical implementation of physical education curriculum plan. The teacher is the main body of physical education curriculum implementation to voluntarily and actively involve in the process of physical education implementation (Wang, \& Hu, 2007). In the implementation of winter sports curriculum in China, there are problems of randomness and blindness in the curriculum implementation in the universities in the Northeast of China. The reasons are that they are mostly affected by the weak faculties, inadequate venue allocation and timeworn equipment.

In addition, imperfect curriculum standards and easy injury have also become important reasons that restrict the implementation of winter sports curriculum (Li, Jiang, \& Sun, 2017). In contrast to Europe and USA, and taking the major of ski area business management of Northern Michigan University as an example, this major is a joint project with Gogebic Community College in Michigan (NMU, 2018). The way of interschool cooperation solves the problem of insufficient teaching resources such as venues and faculties in the curriculum implementation. Students may learn necessary technical skills in community colleges and practice ski resort management or the operation of ski resort functional areas. Innsbruck University (Austria), which takes skiing as research strength, also cooperates with ski resorts and the curriculum implementation is carried out in accordance with basic course plan. It can be seen that the implementation of the European and USA winter sports curriculum is a relatively open and dynamic management process, and there is more space for flexible use in specific operations. 


\subsection{Comparison of Curriculum Evaluation}

- Through interviews, it is found that the winter sports curriculum of professional sports schools in the three northeastern provinces of China mainly focuses on teacher evaluation. Due to the random and blindness problems in the implementation of the curriculum, there is also non-standard phenomenon in curriculum evaluation (Li, Jiang, \& Sun, 2017). Europe and the USA have similar evaluation requirements for winter sports technique curriculum.

- For example, the ski courses of North Carolina State University has specific operational requirements on the skill evaluation in the curriculum evaluation, the skill evaluation accounts for $45 \%$, the theoretical examination accounts for 55\%, and the student's comprehensive score evaluation is classified into 13 grades (from A+ to F (failure) (Syllabus, 2016). The ski area management syllabus of Colorado University definitely indicates that students are required to spend 6-8 hours per week in reading, watch and participate in PPT presentation, participate in forum discussion, complete group homework, meet attendance rate, and complete the final evaluation of curriculum (Colorado, 2017). On the whole, the specific evaluation content and weight ratio of different schools in Europe and the USA are slightly different. What is certain is that the evaluation of winter sports curriculum is carried out by means of multiple comprehensive evaluations, and more emphasis is placed on students' learning effect and comprehensive performance.

\section{Enlightenment to China from European and USA Winter Sports Major Development and Curriculum Setting}

\subsection{Broadening the Major Scope and Add Course Categories}

According to the basic characteristics of Curriculum Plan in China, it is necessary to increase the freedom of school curriculum setting, and realize the industrialization of main courses, disciplinary setting of compulsory courses, the module setting of earlier selective course, and the miniaturization of optional courses. On the one hand, it needs to actively apply for setting up winter sports program, or to set up winter sports orientations according to different majors, or set up different curriculum systems for specific major orientations, forming a course "module" or course "group" and making it possible for students to choose the courses. It is not all major orientations choose the same class. On the other hand, with reference to the mature modes of European and USA winter sports, it is necessary to increase the categories of course, especially the theoretical courses related to the winter sports industry such as ski area management, history of Winter Olympic, and winter sports rescue, etc., and bring them in line with international curriculum as soon as possible.

\subsection{Enriching the Curriculum System and Strengthening the Correlation between Teaching Theory and Practice}

The in-depth conformity between different curriculum contents and curriculum 
objectives enables the theory to effectively correlate with the teaching practice. The activity arrangement of curriculum content can also be flexible. The combination of theory and practice in the form of "workshop" and "field study" makes the curriculum content more correlated and complete, and better guarantees the teaching quality. In the curriculum implementation, it needs to break the traditional restrictions, and carry out joint teaching according to "school conditions". A course can be taught by several teachers, and meanwhile multi-evaluations can be conducted to different types of courses. The structure of winter sports curriculum in different majors should be flexible so as to advance with the times and strive to coordinate different winter sports curriculum system with the formulation of training objectives.

\subsection{Establishing a Multi-Party Cooperative School-Running Mode to Break the Barriers among Universities at Home and Abroad}

On the one hand, through the mode of domestic inter-school cooperation and foreign inter-school exchange, the mutual credit recognition of inter-school courses can be realized to solve the predicament of insufficient teachers and venues. On the other hand, it can also tap and utilize the force of society and adopt the mode of joint operation of schools and enterprises to train winter sports talents. For example, through the cooperation with the skating rink and ski school to recognize part of the course credits, it is suggested to make full use of off-campus existing resources, and strengthen the coordination and organization in the implementation of off-campus curriculum.

\subsection{Strengthening the Construction of Winter Sports Faculties and Realizing the Setting of Multiple Winter Sports Curriculum}

In China, many winter sports theory and technique curriculums cannot be offered. The fundamental reason is the lack of teachers. Therefore, the first problem to be solved for the improvement of Chinese winter sports curriculum setting is the lack of teachers. On the one hand, the universities with adequate conditions can expand its teacher group by introducing or sharing industrial talents. On the other hand, the school needs to increase its self-cultivation efforts, cultivate potential teachers in different disciplines and cross-disciplinary fields, and reserve teacher sources for the realization of multiple disciplines setting.

The higher education in the 21st century has begun to enter a new change era. As a point in the education level, the winter sports should conform to the trend of the times. In the process of referring to the beneficial experience of leading winter sports countries such as Europe and USA, China should find a scientific and feasible winter sports curriculum setting based on own national, folk and school conditions, play the role of cornerstone and become a source of motivation for the training of winter sports talents. 


\section{Acknowledgements}

The authors thank Dr. Liqiang Yu, director of Winter Sport Department at Jilin Sport University, China, and Zhiqiang Zhu, President of Harbin Sport University, for their assistance in setting up and running the project.

\section{Conflicts of Interest}

The authors declare no conflicts of interest regarding the publication of this paper.

\section{References}

Carter, N. (2016). Skiing into Modernity: A Cultural and Environmental History. Social History, 1, 122-123. https://doi.org/10.1080/03071022.2015.1112966

Cong, L. X. (2007). The Problem of Curriculum Theory ( $1^{\text {st }}$ ed.). Beijing: Education Science Press.

Curriculum of Faculty of Sport, University of Ljubljana. https://www.fsp.uni-lj.si/en/study/uni-bachelors-degree/sports-education/curriculum/

Guan, J. C., Dong, Y. K., \& Kang, H. (2009). Contemplation of Opening a Winter Outdoor Sports Course for the Physical Education Major of Institutes of Higher Learning in the Northeast Region. Journal of Physical Education, 9, 89-91.

Han, R., Gu, H. Z., \& Sun, X. B. (2011). Current Situation and Strategic Analysis on Developing the Ice-Snow School Based Curriculum in Universities in Heilongjiang Province. China Winter Sport, 4, 74-78.

Introduction of Ski Business Administration Major, Northern Michigan University. https://www.nmu.edu/bulletin/programs?VersionID=28\&processtype=self\&action $=\mathrm{Pr}$ ogsByDept\&phase $=$ phase $5 \&$ elementid $=\&$ subaction $=1254168943$

Li, W., Jiang, L. X., \& Sun, J. H. (2017). Current Situation and Development Strategies of Snow and Ice Curriculum in Colleges and Universities of Northeast Provinces. China School Physical Education, 1, 60-64.

Liu, B. (2011). References from Professional Curriculum Setting of Sports Training in Germany. Journal of Shanghai University of Sport, 4, 77-80.

Ma, Y., \& Lv, J. H. (2016). Study on Training or National Reserve Elites for Key Events of 2022 Winter Olympics. China Sports Science, 4, 3-10.

Peng, G. Q., \& Shu, S. F. (2014). The Characteristics and Enlightment of Professional Curriculum in American College Recreation Sports. Journal of Sports and Science, 4, 14-19.

Rudolf, M. (2013). The Importance of Skiing in Austria. The International Journal of the History of Sport, 6, 659-673. https://doi.org/10.1080/09523367.2012.760999

Wang, J., \& Hu, Q. S. (2007). Factors of Influencing Physical Education Teacher's Participation in Implementation of Physical Education Curriculums and Countermeasures. Journal of Shanghai University of Sport, 6, 68-74, 92.

Wang, Y., \& Wang, L. G. (2017). Realistic Problems of Teacher Education Development and Professional Training in the Winter Sports. China School Physical Education, 1, 56-59.

Wu, G. (2007). From Curriculum to Learning: The Road of Rebuilding Quality Education ( $1^{\text {st }}$ ed.). Shanghai: Shanghai Education Press.

Zhang, S. B. (2016). Research on the Teaching Mode of Ice Snow Course under the New 
Situation. China Winter Sport, 3, 49-52.

Zhao, Q., Li, M. D., Li, H. Y., \& Li, W. D. (2016). Research on the Curriculum Setting of Physical Education Major at Ohio State University in the United States: Characteristics, Philosophical Beliefs, and Inspirations. Journal of Beijing Sport University, 12, 105-111.

Zhong, Q. Q. (2008). The Logistic of Curriculum (1 $1^{\text {st }}$ ed.). Shanghai: East China Normal University Press. 